\title{
Complement and macrophage crosstalk during process of angiogenesis in tumor progression
}

\author{
M. Afzal Khan ${ }^{1 *}$, A. M. Assiri ${ }^{1}$ and D. C. Broering ${ }^{2}$
}

\begin{abstract}
The complement system, which contains some of the most potent pro-inflammatory mediators in the tissue including the anaphylatoxins C3a and C5a are the vital parts of innate immunity. Complement activation seems to play a more critical role in tumor development, but little attention has been given to the angiogenic balance of the activated complement mediators and macrophage polarization during tumor progression. The tumor growth mainly supported by the infiltration of M2- tumor-associated macrophages, and high levels of C3a and C5a, whereas M1-macrophages contribute to immune-mediated tumor suppression. Macrophages express a cognate receptors for both C3a and C5a on their cell surface, and specific binding of $\mathrm{C} 3 \mathrm{a}$ and $\mathrm{C} 5 \mathrm{a}$ affects the functional modulation and angiogenic properties. Activation of complement mediators induce angiogenesis, favors an immunosuppressive microenvironment, and activate cancer-associated signaling pathways to assist chronic inflammation. In this review manuscript, we highlighted the specific roles of complement activation and macrophage polarization during uncontrolled angiogenesis in tumor progression, and therefore blocking of complement mediators would be an alternative therapeutic option for treating cancer.
\end{abstract}

Keywords: Tumor progression, Complement mediated injury, Angiogenesis, Macrophage

\section{Introduction}

The complement system has been primarily considered as an effector of innate immunity with the ability to antibody-mediated disposal of foreign particles, apoptotic clearance, and actively maintain the phase of immune surveillance in different inflammatory states [1-4]. The complement activation play a dual role in tumor development, and it has been reported that it can control tumor activities through acute inflammation, immunostimulation, lysis, opsonization and chemotaxis [5]. In contrast, the complement activation also support chronic inflammation, promote an immunosuppressive microenvironment, induce angiogenesis, and activate cancer-related signaling pathways during tumor progression [6]. Process of angiogenesis is firmly regulated by the balance of two sets of counteracting mediators

\footnotetext{
* Correspondence: mkhan26@kfshrc.edu.sa

'Department Comparative Medicine, King Faisal Specialist Hospital and Research Centre, MBC 03, P.O. Box 3354, Riyadh 11211, Kingdom of Saudi Arabia

Full list of author information is available at the end of the article
}

known as- angiogenic activators and inhibitors [7]. The stage of 'angiogenic-switch' determines the time of initiation of succeeding angiogenic phase and a physiological up-regulation of angiogenic stimulators than angiogenic inhibitors, as in the case of wound healing, which will turn-on angiogenic switch to speed up the process of normal angiogenesis $[8,9]$. During the process of normal angiogenesis, each step is tightly remained under the control of different immune regulators but in some pathological cases, the 'angiogenic-switch' remains in the active state, which leads to uncontrolled angiogenesis in many physiological disorders including tumor progression [10]. Malignant cells are able to maintain a balance between complement activation and inhibition thereby manipulates most advantages of complement initiation without suffering its destructive effects [11, 12]. In this perspective, inhibition or blocking of complement mediators would be a potential therapeutic option for treating cancer [12-14]. This review further highlights how

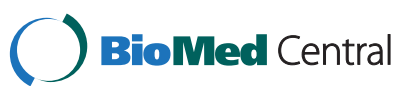

(c) 2015 Khan et al. This is an Open Access article distributed under the terms of the Creative Commons Attribution License (http://creativecommons.org/licenses/by/4.0), which permits unrestricted use, distribution, and reproduction in any medium, provided the original work is properly credited. The Creative Commons Public Domain Dedication waiver (http:// creativecommons.org/publicdomain/zero/1.0/) applies to the data made available in this article, unless otherwise stated. 
cancer cells manipulates complement mechanism to protect their proliferation, and survival by recruiting tumor-associated macrophages (TAMs) and facilitates tumor progression.

\section{A. How do tumor cell skip anti-tumor effects of inflammation?}

Tumor progression has a unique property, which makes tumor cells to skip the anti-tumor effects of inflammation in order to polarize immune responses toward those effectors that facilitates tumor progression. It has been reported that cancer cells adopt a variety of cellular machineries to trick complement-mediated injury [15]. The deleterious roles of complement mediators on the eradication of tumors have not been investigated in details. However, by virtue, complement has tendency to recognize non-self-elements, and it is interesting to note that any structural manipulations in the tumor cell membranes make these cells an easy target for complement attack, and a number of clinical studies have reported an activation of complement in cancer patients $[16,17]$. The activation of complement cascade release key anaphylatoxins $\mathrm{C} 5 \mathrm{a}$ and $\mathrm{C} 3 \mathrm{a}$, which are potent chemo-attractants for macrophages, eosinophils, monocytes, and T cells $[18,19]$ and modulate complement mediated tissue injury through the release of cytokines, eicosanoids, and reactive oxygen species $[18,19]$. To protect from the complement, cancer cells develop a variety of configurational strategies to combat complementmediated damage [15]. Due to these structural manipulations, though, malignant cells are recognized by complement mediators but survive complement mediated lysis through the shielding role of complement regulatory proteins [20] (Fig. 1). This regulated complement activation provides a permanent source of complement mediators that could support the tumor growth favorable inflammatory microenvironment $[21,22]$, and it was shown in number of in-vitro cancer cell line studies that the overproduction of complement activation product C5a [5]. In addition, elevated levels of plasma C5a has been reported in Lung cancer [5, 23], and in other tissue specific cancers [23, 24]. Furthermore, It has been found in number of cancer models that tumor inflammatory microenvironment constitutes complement activated fragments $\mathrm{C} 3, \mathrm{C} 4$, and $\mathrm{C} 5$, Clq, and MAC [12], high levels of IL-6 [25] and TGF- $\beta$ [26]. IL-6 has been shown to assist tumor progression though apoptosis inhibition, angiogenesis stimulation [27].

\section{B. Complement cascade mediators:}

The complement cascade consists of plasma and membrane-bound proteins, which protects against immune-mediated tissue injury in different pathogenic conditions [28]. Activation of complement cascade initiated through three different pathways: the classical pathway, the lectin pathway, and the alternative pathway.

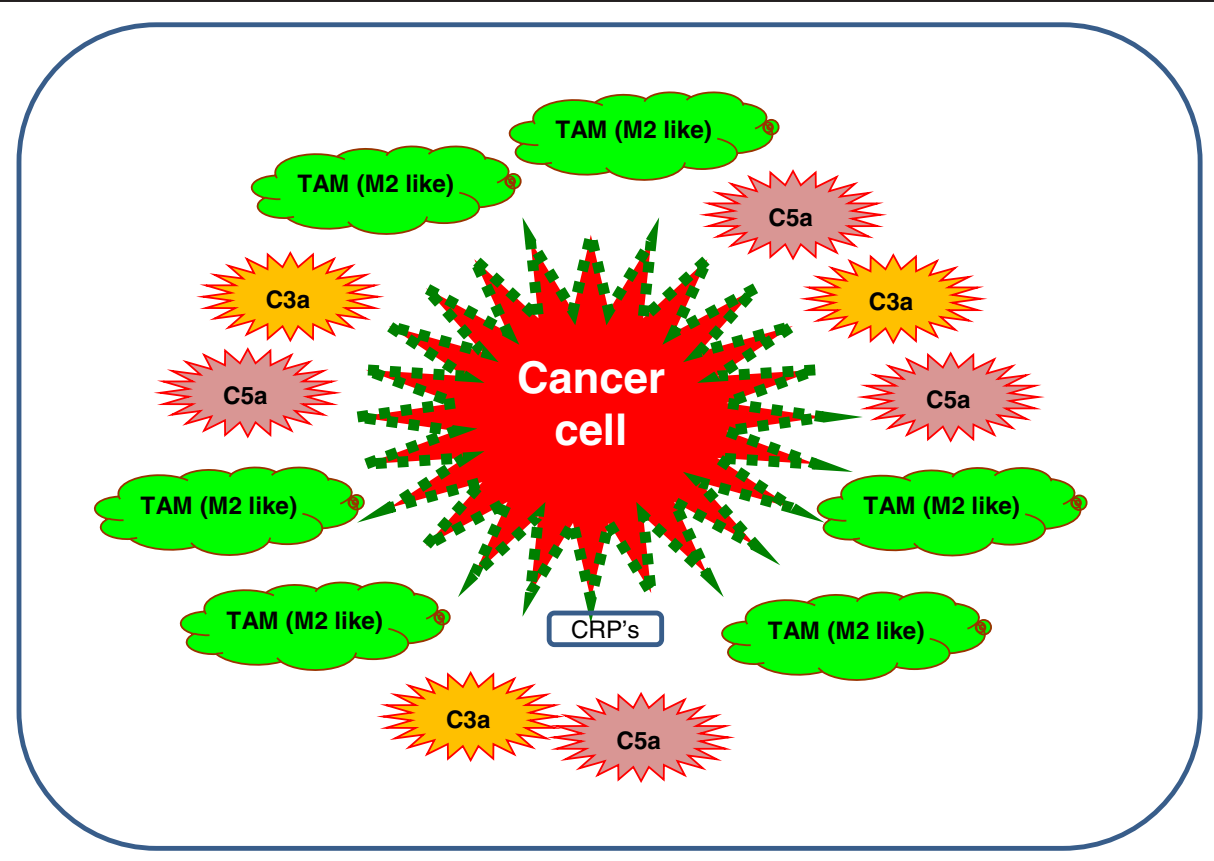

Fig. 1 Mechanism of cancer cell protection. Model illustrates the shielding mechanism orchestrated by cancer cells to protect against host effector immune responses. It shows complement resistant cancer cells are hugely infiltrated with C3a and C5a, TAMs and over-expressed complement regulatory proteins (GREEN dots) 
The three pathways all converge in the activation of the pivotal complement molecule $\mathrm{C} 3$ and generate $\mathrm{C} 3$ convertase [29]. This C3 convertase promotes the cleavage of C3 into C3a and C3b. After cleavage of C3, C3b molecule combines with the $\mathrm{C} 3$ convertase to form $\mathrm{C} 4 \mathrm{bC} 2 \mathrm{aC} 3 \mathrm{~b}$ complex in classical and lectin pathways, and to the formation of $\mathrm{C} 3 \mathrm{bBbC} 3 \mathrm{~b}$ complex in the alternative pathway. Both $\mathrm{C} 4 \mathrm{bC} 2 \mathrm{aC} 3 \mathrm{~b}$ and $\mathrm{C} 3 \mathrm{bBbC} 3 \mathrm{~b}$ complexes are known as C5 convertase and cleaves C5 into C5a and C5b molecules. The generated $\mathrm{C} 5 \mathrm{a}$ can then function as a potent anaphylatoxin at the site of production while C5b participates in the assembly of the membrane attack complex (C5b-9 or MAC) [29]. Finally, MAC complex can initiate cell lysis, and in sublytic quantities can lead to cell activation (Fig. 2). The main sources of C3 in human are hepatocytes [30], but C3 is also expressed by macrophages [31], fibroblasts [32], vascular endothelium [33], astroglia [34] and adipocytes [35]. Beside of involvement in complement activation, $\mathrm{C} 3$ and its degradation products are able to promote phagocytosis, activate inflammatory responses against pathogens, and regulate adaptive immune, but uncontrolled activation may result in host cell damage [36]. The complement cascade plays a vital role in antimicrobial defense and the clearance of immune complexes and apoptotic cells [37]. This latter property is a recognized pathogenic factor in a wide spectrum of chronic inflammatory diseases, including rheumatoid arthritis, glomerulonephritis, atherosclerosis, asthma, and multiple sclerosis [38]. Substantial research has proven the evidence of the activated complement mediators in cellular proliferation, and diseases of chronic inflammation, which suggest a potentially deleterious role in abnormal cellular growth $[18,39]$. Thus, it is not overwhelming that signals for complement-mediated disease pathogenesis has centered mainly on the dysfunctional immunity caused by the absence, alteration, or over activation of complement proteins [39]. It has been reported that complement proteins mediate cellular turnover, growth, and regeneration, including bone marrow stem cell engraftment, bone and cartilage development, neurogenesis, synaptogenesis, white matter healing, and regeneration of the liver, limb, and lens [12, 40, 41].

\section{Macrophages during tumor progression:}

Macrophages are an important component of the innate immune system, they are characterized by the expression of number of unique surface markers including CD14, CD11b, CD11c, F4/80, MAC-1/MAC-3, CD163, and CD68 [42, 43]. It has been found in number of tumor models that macrophages support cancer cells proliferation and survival [44]. Macrophage release

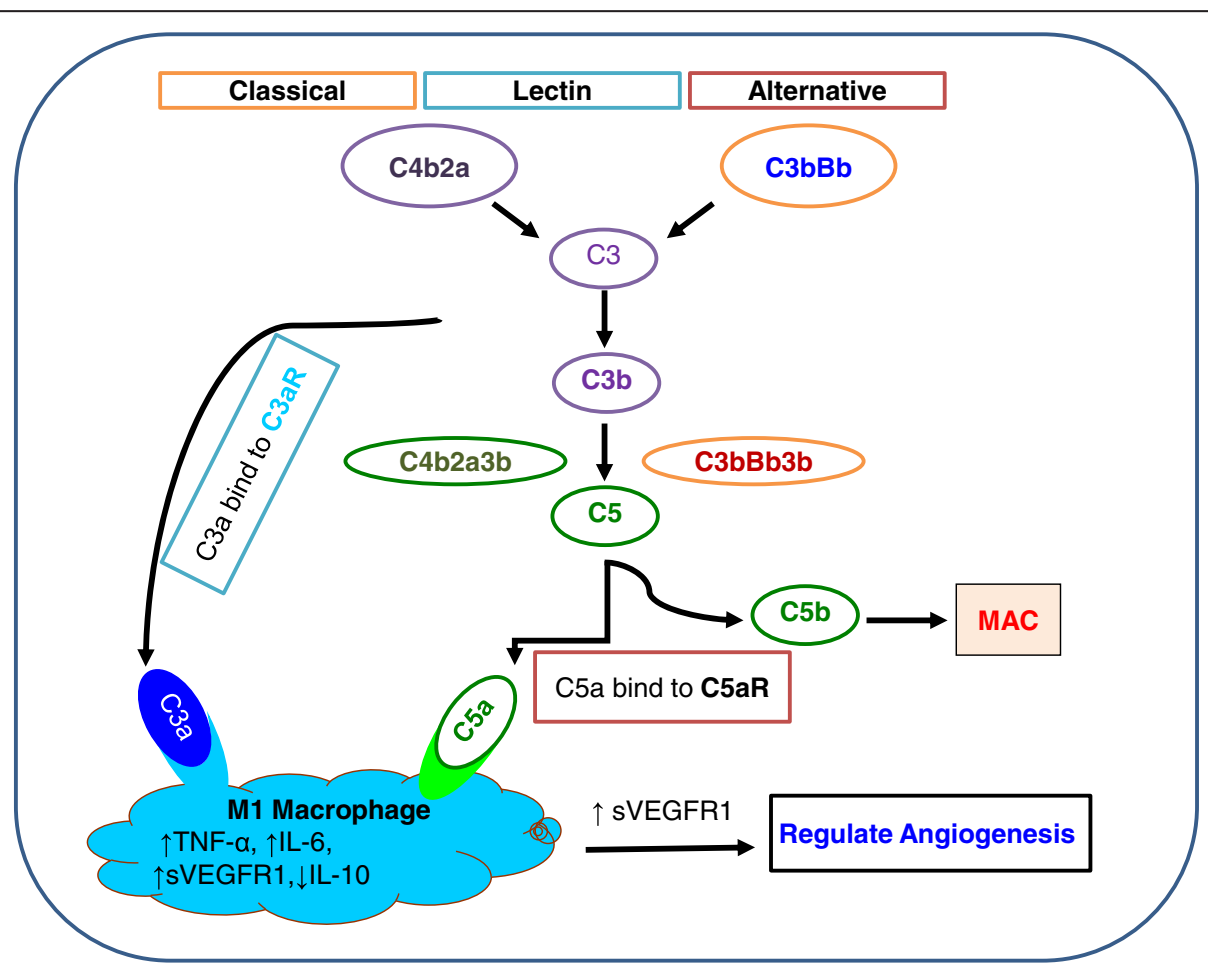

Fig. 2 Macrophage polarization: Model illustrates $M 1$ and $M 2$ macrophage mediated angiogenesis in tumor development. M2 macrophages promote tumor growth through the release of TGF- $\beta$, IL-10, IL-17, IL-23, VEGF, and FGF2 required for tumor growth. In contrast, M1 macrophages suppress tumor growth through the release IFN- $\mathrm{IL}-12$, and TNF- $\alpha$ 
TNF- $\alpha$ and activate NF-kB, which turns-on proteins that stop apoptosis, and promote cell proliferation [45-47]. Macrophages maintain essentials of tissue remodeling, inflammation, and immunity, include endocytosis of foreign and necrotic debris, cytotoxicity, and secretion of more than different cytokines [48-50]. However, depending on their activation, macrophages are able to secrete growth factors, prostaglandins, interferon, elastase, plasminogen activator, and collagenase, and complement components C3 and C5 [51]. Macrophages have classically activated M1 and alternatively activated M2 subtypes, and the differentiation in to respective subtype is mediated through the release of cytokines and growth factors present in the inflammatory microenvironment [52-54]. The development of M1 macrophages stimulated through IFN- $\gamma$ and TNF- $\alpha$ [55], whereas, the M2 macrophages are polarized by IL-4, IL-13 [54]. As mentioned, the immunological effects of both M1 and M2 subtypes are regulated through the myriad of cytokines. It has been reported that IFN- $\gamma$ stimulated M1 macrophages elevate the production of IL-12 and IL-23, and low IL-10 [50, 56]. However, M2 macrophages favor over production of IL-10 and low levels of IL-12 and IL-23 $[56,57]$. M1 macrophage secreted IL-12 promotes the differentiation of Th1 cells, which can improve antigen phagocytosis [48], while IL-23 triggers the Th17 cells proliferation and release of IL-17, which modulates inflammatory autoimmune pathologies [58, 59]. On the other side, the M2 macrophage secreted IL-10 favor the production of IL-4 and IL-13 by Th2 cells [60]. The M1 macrophage derived chemokines are also critical for killing intercellular pathogens, whereas the M2 macrophage derived chemokines promote the recruitment of the leukocytes involved in tissue repair and remodeling process [54]. It has been reported that macrophage polarization occurs during onset of tumor progression and it changes from classically activated M1 to alternatively activated M2 like Tumor-Associated Macrophages (TAMs) [54]. Depending on the physiological and pathological conditions, macrophages undergo differentiation into M1 and M2 phenotypes and both play a key role in maintaining tumor growth [61]. M1 macrophages are pro-inflammatory in function, they secrete IFN- $\gamma$, IL- 12 and TNF- $\alpha$, and therefore effectively suppress tumor growth $[62,63]$ while M2 like TAMs secrete TGF- $\beta$, IL-10, IL-17, IL-23, VEGF, and FGF2 [62], promote angiogenesis and tumor progression (Fig. 3). M2 TAMs produce VEGF, FGF chemokines IL-17, IL-23, or TGF- $\beta$ that contribute to stimulation of vascular endothelial cell proliferation, release of MMPs, which degrade the vascular basement membrane and induce sprouting, migration of endothelial cells into the tumor and this process further leads to tube formation and maturation of new microvessel. [62]. M2 TAMs promotes the proliferation of tumor cells directly by secreting growth factors, and participate in tumor progression by acting on endothelial cells, and thus promoting the neovascularization of the tumor $[49,62,64]$. M2 TAMs are the key player during

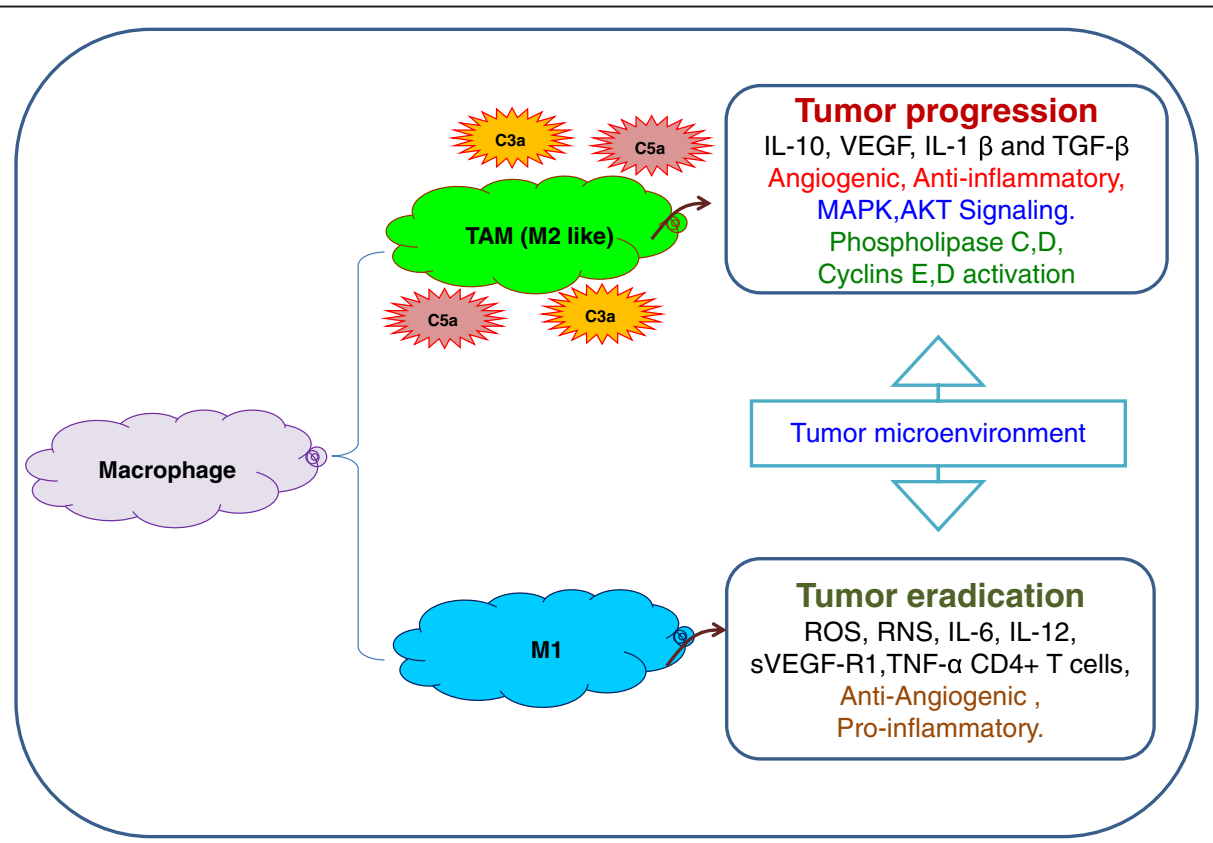

Fig. 3 Regulation of angiogenesis. Model illustrates macrophage-mediated regulation of angiogenesis: This explains how complement mediators regulate the phase of angiogenesis under normal physiological conditions 
angiogenesis and promote each step of the angiogenesis cascade $[56,65,66]$. The angiogenic phenotype of macrophages is in part defined by their ability to secrete molecules that promote or inhibit angiogenesis [54, 56, 65-67]. During tumor progression, M2 TAMs are migrated to tumors under the influence of various cytokines and growth factors secreted by cancer and stromal cells. However, it has been shown that M1 macrophages express IFN- $\gamma$, IL-1, and IL-6, which prime T-cell towards anti-tumor type-1 inflammatory response [68]. However, in most tumors such as breast, prostate, ovarian, cervical, lung carcinoma, and cutaneous melanoma, M2 TAMs are considered to be anti-inflammatory and correlated with a poor prognosis [56, 69]. M2 TAMs mostly occupy hypoxic regions of tumors, and express more proangiogenic genes, such as VEGF, pFGF, CXCL8, and glycolytic enzymes, through the transcription factors HIF- $1 \alpha$ and HIF-2 [70, 71]. Most TAMs display M2 associated molecules, which includes IL-10 and MGL1, as well as CCL2, CCL5, CXCL9, CXCL10, and CXCL16, and heat shock proteins [72, 73]. In addition, the tumor microenvironment, which includes IL-4, IL-13, TGF- $\beta$, and IL-10 further support the adoption of an M2 phenotype [54]. M2 TAMs are associated with different stages of tumor development, which includes tumor progression, angiogenesis, uncontrolled growth, actual metastasis, immunosuppression, matrix deposition, and tissue remodeling [56, 74]. It has been reported that M2 TAMs are able to modulate and induce neovascularization and support functions. In addition, activated TAMs release growth factors (VEGF and PDGF), cytokines (TGF- $\beta$ ), proteases, and chemokines, which promote angiogenesis in many tumors, such as gliomas, squamous cell carcinomas of the esophagus, and breast, bladder, and prostate carcinomas [56, 65]. Moreover, TAM-secreted matrix metalloproteases (MMP1, MMP-2, MMP-3, MMP-9, and MMP-12), and plasmin are also support angiogenesis [75]. In addition, MMP-9 support angiogenesis through the release of VEGF signaling [76]. TAMs preferentially accumulate in hypoxic and necrotic regions within the tumors and become M2-angiogenic [62].

\section{Complement activation during angiogenesis and in tumor progression:}

The complement regulates both innate and adaptive immune systems, and more particularly during the phase of acute inflammation, complement anaphylatoxins C3a and C5a mediates changes in microvascular flow, permeability, leukocyte extravasation and migration, which contributes to tissue damage after ischemia reperfusion and in other disease models [2,77]. The active complement proteins, $\mathrm{C} 3 \mathrm{a}$ and $\mathrm{C} 5 \mathrm{a}$, control macrophage mediated angiogenesis in tissue [12, 40, 41]. C3a and C5a generated from complement cascade have potential effects on macrophage-mediated angiogenesis inhibition. Both $\mathrm{C} 3 \mathrm{a}$ and $\mathrm{C} 5 \mathrm{a}$ anaphylatoxins bind to their respective C3aR and C5aR on monocytes/macrophages [78] and many other cells including airway epithelium, causing an anti-angiogenic response resulted in an increased IL-6, TNF- $\alpha$, sVEGFR1, and decreased IL-10 mRNA. Increased sVEGFR1 secretion from monocytes/macrophages inhibits angiogenesis in different disease models [40, 41] (Fig. 2). It has been well established in transplants model that $\mathrm{C}^{-/-}$recipients mice exhibited more dilated and leaky microvessels as compare to the control allografts [2, 77]. In addition, the latest research outcomes in mouse model of retinopathy reveals the importance of complement in regulating increased neovascularization in $\mathrm{C}^{-1-}$ mice compared with control groups [79]. Along with $\mathrm{C} 3$ role in neovascularization, C5a also play a crucial role in angiogenesis, and increased neovascularization was observed in $\mathrm{C}_{5} \mathrm{aR}^{-1-}$ mice compared with control group [79]. C5aR antagonist supported the process of neovascularization, whereas treatment with $\mathrm{C} 5 \mathrm{a}$ agonist reduced neovascularization in retinopathy model, confirming the inhibitory role of $\mathrm{C} 5 \mathrm{a}$ and $\mathrm{C} 5 \mathrm{aR}$ in this process [79]. Moreover, treatment of $\mathrm{C}^{-/-}$with $\mathrm{C3a}$ and $\mathrm{C} 5 \mathrm{a}$ reduced the enhanced neovascularization effect observed in $\mathrm{C}^{-/-}$mice, suggesting that $\mathrm{C} 3 \mathrm{a}$ and $\mathrm{C} 5 \mathrm{a}$ are inhibitory effectors of pathologic hypoxia-driven retinal neovascularization [79].

Complement proteins have been reported to facilitate tumor progression through the dysregulation of mitogenic signaling pathways, continuous cellular proliferation, angiogenesis, insensitivity to apoptosis, invasion and migration, and escape from immunosurveillance $[12,14,80]$. During the phase of tumor progression, complement anaphylatoxins C3a and C5a increase mitogenic signaling pathways. The cell inducing abilities of the C3a and C5a have been reported [81] and also revealed the involvement in several other signal transduction pathways with known links to neoplastic progression (Fig. 3). In addition, complement receptors (C3aR1) and (C5aR1) are coupled to G-proteins and mostly present in M2 macrophages, airway epithelium, and parenchymal vessels. Number of research findings have shown that the membrane attack complex, which is one of the main terminal product of complement cascade, also activates the cell cycle and oncogenic pathways [82, 83]. It is well known and established that under hypoxic conditions, progression from a small population of neoplastic cells to a clinically significant mass requires creation of new microvessels to perfuse the newly formed malignant tissue structure [84]. Moreover, number of studies has revealed that the extent of tumor vessels formation suggested a direct link between 
increased angiogenesis and tumor aggressiveness, can predict the growth rate and progression of the disease [85]. Activation of complement cascade has been examined through in-vitro studies of cancer cell lines and I was found that Lung cancer cells are able to produce C5a more efficiently than do non-malignant bronchial epithelial cells but the mechanism is still not yet explained [5]. The classical pathway has been recognized as the major contributor to complement activation on subcutaneously inoculated TC-1 cervical cancer cells [13] and in two neuroblastoma cell lines in vitro [17]. In the case of primary tumors, Lucas et al. [86] have reported that a tumor-specific immune activation occurs in papillary thyroid carcinomas, with activation of the classical pathway. In addition, role of classical pathway has also been reported in follicular, MALT lymphomas [87], and in patients with chronic lymphocytic leukemia [88]. In contrast, the results of other studies has demonstrated that lymphoma and myeloma cells activate the alternative pathway of the complement cascade [89]. Furthermore, both the alternative and the classical cascade has also been reported in some cases [90, 91], while the lectin pathway has been found to be significantly activated in colorectal cancer patients. The immuno regulatory functions of $\mathrm{C} 3 \mathrm{a}$ and $\mathrm{C} 5 \mathrm{a}$ and their receptors (CR) has been characterized in cancer models, and it was found that number of myeloid-derived innate immune cells express $\mathrm{C} 3 \mathrm{aR}$ and $\mathrm{C} 5 \mathrm{aR}$, including monocytes, macrophages, DCs, neutrophils, basophils, T cells, mast cells, and eosinophils [92-94]. Through, its influence on innate immune cells including DCs and macrophages, C3a similarly regulates the $\mathrm{T}$ cell response, especially the determination of Th1 cells [14].

\section{Conclusions}

The complement system help innate immune attack against cancer cells through cytotoxic and lytic effects but number of studies are revealing that the complement cascade enables a remarkable array of proliferative events [20]. Both complement and macrophages interact closely to maintain process of angiogenesis, and modulate the major features of carcinogenesis, including dysregulation of mitogenic signaling pathways, sustained cellular proliferation, angiogenesis, and insensitivity to apoptosis, invasion, metastasis, and escape from immunosurveillance. Macrophages also tune inflammation and adaptive immunity, promote cell proliferation by release of number of growth factors, ornithine, and polyamines. They also take active role in promoting angiogenesis, tissue remodeling, and tissue repair $[66,95,96]$. M2 macrophages acts as a tumor promoters at distinct phases of malignant progression of gastric, mammary [97], lung [98], and liver carcinomas [99]. Macrophages express receptors for activated $\mathrm{C} 3$ and $\mathrm{C} 5$, respond to activated $\mathrm{C} 3 \mathrm{a}$ and C5a mediators at the site of local inflammation, and maintain angiogenesis in tissue [79]. There are significant research evidences, which support the contribution of complement activation to tumor progression [22, 24, 100]. During tumor progression, tumor cells undergo genetic and epigenetic manipulations that modulate their malignant growth $[5,101,102]$. Due to these manipulations, the complement system can differentiate and recognize tumor cells from non-malignant cells [29, 103, 104], which protect cancer cells from deleterious effects of complement mediators [105]. It has been demonstrated in mouse model of cervical cancer that the generation of $\mathrm{C} 5 \mathrm{a}$ in the tumor microenvironment promotes tumor progression through the recruitment of myeloid-derived suppressor cells and the generation of an immunosuppressive microenvironment [106]. However, in lung carcinogenesis model, C5a play a key role as a mediator in the regulation of cancer growth [5], and targeted inhibition of the C5a bindings to its receptors could inhibit the microenvironment without diminishing the protective effects of complement activation [107]. In addition to its antiinflammatory role, complement play a crucial role in several transduction pathways involved in tumor progression. $\mathrm{C} 5 \mathrm{a}$ is a key regulator of complement mediated inflammatory response during tumor progression [18]. The therapeutic blockade of the complement system to suppress tumor progression has been investigated by antagonizing the C5aR receptor [13], and it was suggested that tumor cells evade lysis by the use of protective mechanism that limits the formation of functional MAC pores [108]. In addition, It has been demonstrated that MAC activates cancer-associated signaling pathways through MAPK, phosphatidylinositol 3-kinase, Ras, and p70 S6 kinase $[82,109,110]$, and inhibit apoptosis cancer cells by blocking FLIP, caspase-8 [111].

These findings reflects that cancer cells utilize complement modulation as a shield to protect itself from surrounding effector molecules, and thereby favors tumor progression. This unique adoptability of cancer cells uncover the key importance of targeted complement inhibition to restrict tumor growth $[105,112]$. A number of studies are targeting the potential role for complementmediated therapeutics options to rescue tissue from tumor progression. There is particular interest in the applications of monoclonal antibodies against the soluble and membrane-bound complement inhibitors reported by different tumors, an approach believed to enhance antitumor complement-dependent cytotoxicity and antibody-dependent cell-mediated cytotoxicity. However, the increasingly interest of complement interaction with tumor cells demands further information, and suggest possibility that anti-complement strategies $[2,77]$ may offer an entirely new means of fighting number of complement mediated diseases including 
cancer and tumor progressions. This review uncover the cross-talk between complement proteins and macrophages on tumor progression and future of complement as a potential therapeutic target to rescue tissue from tumor progression.

\section{Abbreviations}

C3AR1: Complement component 3a Receptor 1; C5AR1: Complement component 5a Receptor 1; CR: Complement receptor; ECM: Extra cellular matrix; FGF: Fibroblast growth factor; MAC-1 \& -3: Macrophage-1 \& -3 antigen; MAC: Membrane attack complex; MMPs: Matrix metallo peptidase; MALT: Mucosa-associated lymphoid tissue; PDGF: Platelet-derived growth factor; PGD2: Prostaglandin D2; TAMs: Tumor-associated macrophages.

\section{Competing interests}

The authors declare that they have no competing interests.

\section{Authors' contributions}

MAK has been involved in writing, compiling the manuscript, and in revising it critically for publication standards; AMA and DCB contributed significantly on literature and critical suggestions to reshape the manuscript. All authors read and approved the final version of manuscript.

\section{Acknowledgments}

The author would like to thanks Dr. Suhail Akhtar (sakhtar@luriechildrens.org), Stanley Manne Children's Research Institute, Chicago, USA, for critically reading this manuscript.

\section{Author details}

'Department Comparative Medicine, King Faisal Specialist Hospital and Research Centre, MBC 03, P.O. Box 3354, Riyadh 11211, Kingdom of Saudi Arabia. ${ }^{2}$ Organ Transplant Centre, King Faisal Specialist Hospital and Research Centre, Riyadh, Kingdom of Saudi Arabia.

Received: 23 February 2015 Accepted: 25 May 2015

Published online: 22 July 2015

\section{References}

1. Khan MA. Inflammation signals airway smooth muscle cell proliferation in asthma pathogenesis. Multidiscip Respir Med. 2013;8(1):11.

2. Khan MA, Nicolls MR. Complement-mediated microvascular injury leads to chronic rejection. Adv Exp Med Biol. 2013;734:233-46.

3. Khan MA, Nicolls MR, Surguladze B, Saadoun I. Complement components as potential therapeutic targets for asthma treatment. Respir Med. 2014;108(4):543-9.

4. Kwan WH, van der Touw W, Heeger PS. Complement regulation of T cell immunity. Immunol Res. 2012;54(1-3):247-53.

5. Corrales L, Ajona D, Rafail S, Lasarte JJ, Riezu-Boj Jl, Lambris JD, et al. Anaphylatoxin C5a creates a favorable microenvironment for lung cancer progression. J Immunol. 2012;189(9):4674-83.

6. Pio R, Ajona D, Lambris JD. Complement inhibition in cancer therapy. Semin Immunol. 2013;25(1):54-64

7. Pollina EA, Legesse-Miller A, Haley EM, Goodpaster T, Randolph-Habecker J, Coller HA. Regulating the angiogenic balance in tissues. Cell Cycle. 2008;7(13):2056-70.

8. Nishida N, Yano H, Nishida T, Kamura T, Kojiro M. Angiogenesis in cancer. Vasc Health Risk Manag. 2006;2(3):213-9.

9. Prager GW, Poettler M, Unseld M, Zielinski CC. Angiogenesis in cancer: Anti-VEGF escape mechanisms. Translational Lung Cancer Research. 2012;1(1):14-25.

10. Papetti M, Herman IM. Mechanisms of normal and tumor-derived angiogenesis. Am J Physiol Cell Physiol. 2002;282(5):C947-970.

11. Gunn L, Ding C, Liu M, Ma Y, Qi C, Cai Y, et al. Opposing roles for complement component $\mathrm{C} 5 \mathrm{a}$ in tumor progression and the tumor microenvironment. J Immunol. 2012;189(6):2985-94.

12. Rutkowski MJ, Sughrue ME, Kane AJ, Mills SA, Parsa AT. Cancer and the complement cascade. Molecular Cancer Research: MCR. 2010;8(11):1453-65.

13. Markiewski MM, DeAngelis RA, Benencia F, Ricklin-Lichtsteiner SK, Koutoulaki A, Gerard C, et al. Modulation of the antitumor immune response by complement. Nat Immunol. 2008;9(11):1225-35.
14. Sayegh ET, Bloch O, Parsa AT. Complement anaphylatoxins as immune regulators in cancer. Cancer Medicine. 2014;3(4):747-58.

15. Jurianz K, Ziegler S, Garcia-Schuler H, Kraus S, Bohana-Kashtan O, Fishelson $Z$, et al. Complement resistance of tumor cells: basal and induced mechanisms. Mol Immunol. 1999;36(13-14):929-39.

16. Gasque P, Morgan BP. Complement regulatory protein expression by a human oligodendrocyte cell line: cytokine regulation and comparison with astrocytes. Immunology. 1996;89(3):338-47.

17. Gasque P, Thomas A, Fontaine M, Morgan BP. Complement activation on human neuroblastoma cell lines in vitro: route of activation and expression of functional complement regulatory proteins. I Neuroimmunol. 1996;66(1-2):29-40.

18. Guo RF, Ward PA. Role of C5a in inflammatory responses. Annu Rev Immunol. 2005;23:821-52.

19. Sarma VJ, Huber-Lang M, Ward PA. Complement in lung disease. Autoimmunity. 2006;39(5):387-94.

20. Fishelson Z, Donin N, Zell S, Schultz S, Kirschfink M. Obstacles to cancer immunotherapy: expression of membrane complement regulatory proteins (mCRPs) in tumors. Mol Immunol. 2003;40(2-4):109-23.

21. Gancz D, Fishelson Z. Cancer resistance to complement-dependent cytotoxicity (CDC): Problem-oriented research and development. Mol Immunol. 2009;46(14):2794-800.

22. Kolev M, Towner L, Donev R. Complement in cancer and cancer immunotherapy. Arch Immunol Ther Exp (Warsz). 2011;59(6):407-19.

23. Gminski J, Mykala-Ciesla J, Machalski M, Drozdz M, Najda J. Immunoglobulins and complement components levels in patients with lung cancer. Romanian Journal of Internal Medicine =Revue roumaine de medecine interne. 1992;30(1):39-44.

24. Bjorge L, Hakulinen J, Vintermyr OK, Jarva $H$, Jensen TS, Iversen $O E$, et al. Ascitic complement system in ovarian cancer. Br J Cancer. 2005;92(5):895-905.

25. Deng H, Guo RF, Li WM, Zhao M, Lu YY. Matrix metalloproteinase 11 depletion inhibits cell proliferation in gastric cancer cells. Biochem Biophys Res Commun. 2005;326(2):274-81.

26. Gionanlis L, Alexopoulos E, Papagianni A, Leontsini M, Memmos D. Fibrotic mechanisms in idiopathic rapidly progressive glomerulonephritis: the role of TGF-beta1 and C5b-9. Ren Fail. 2008;30(2):239-46.

27. Guo Y, Xu F, Lu T, Duan Z, Zhang Z. Interleukin-6 signaling pathway in targeted therapy for cancer. Cancer Treat Rev. 2012;38(7):904-10.

28. Klos A, Tenner AJ, Johswich KO, Ager RR, Reis ES, Kohl J. The role of the anaphylatoxins in health and disease. Mol Immunol. 2009;46(14):2753-66.

29. Ricklin D, Hajishengallis G, Yang K, Lambris JD. Complement: a key system for immune surveillance and homeostasis. Nat Immunol. 2010;11(9):785-97.

30. Ramadori G, Rasokat H, Burger R, Meyer Zum Buschenfelde KH, Bitter-Suermann D. Quantitative determination of complement components produced by purified hepatocytes. Clin Exp Immunol. 1984;55(1):189-96.

31. Mogilenko DA, Kudriavtsev IV, Trulioff AS, Shavva VS, Dizhe EB, Missyul BV, et al. Modified low density lipoprotein stimulates complement C3 expression and secretion via liver $X$ receptor and Toll-like receptor 4 activation in human macrophages. J Biol Chem. 2012;287(8):5954-68.

32. Katz Y, Strunk RC. Synovial fibroblast-like cells synthesize seven proteins of the complement system. Arthritis Rheum. 1988;31(11):1365-70.

33. Warren HB, Pantazis P, Davies PF. The third component of complement is transcribed and secreted by cultured human endothelial cells. Am J Pathol. 1987;129(1):9-13.

34. Levi-Strauss $M$, Mallat M. Primary cultures of murine astrocytes produce $C 3$ and factor $\mathrm{B}$, two components of the alternative pathway of complement activation. J Immunol. 1987;139(7):2361-6.

35. Choy LN, Rosen BS, Spiegelman BM. Adipsin and an endogenous pathway of complement from adipose cells. J Biol Chem. 1992;267(18):12736-41.

36. Seya T, Hara T, Matsumoto M, Sugita Y, Akedo H. Complement-mediated tumor cell damage induced by antibodies against membrane cofactor protein (MCP, CD46). J Exp Med. 1990;172(6):1673-80.

37. Wills-Karp M. Complement activation pathways: a bridge between innate and adaptive immune responses in asthma. Proc Am Thorac Soc. 2007:4(3):247-51.

38. Cravedi P, van der Touw W, Heeger PS. Complement regulation of T-cell alloimmunity. Semin Nephrol. 2013;33(6):565-74.

39. Carroll MC. The complement system in regulation of adaptive immunity, Nat Immunol. 2004;5(10):981-6.

40. Rutkowski MJ, Sughrue ME, Kane AJ, Ahn BJ, Fang S, Parsa AT. The complement cascade as a mediator of tissue growth and regeneration. 
Inflammation research: Official Journal of the European Histamine Research Society. 2010;59(11):897-905.

41. Rutkowski MJ, Sughrue ME, Kane AJ, Mills SA, Fang S, Parsa AT. Complement and the central nervous system: emerging roles in development, protection and regeneration. Immunol Cell Biol. 2010;88(8):781-6.

42. Coffelt SB, Lewis CE, Naldini L, Brown JM, Ferrara N, De Palma M. Elusive identities and overlapping phenotypes of proangiogenic myeloid cells in tumors. Am J Pathol. 2010;176(4):1564-76.

43. Coffelt SB, Tal AO, Scholz A, De Palma M, Patel S, Urbich C, et al. Angiopoietin-2 regulates gene expression in TIE2-expressing monocytes and augments their inherent proangiogenic functions. Cancer Res. 2010;70(13):5270-80.

44. van der Bij GJ, Bogels M, Oosterling SJ, Kroon J, Schuckmann DT, de Vries $H E$, et al. Tumor infiltrating macrophages reduce development of peritoneal colorectal carcinoma metastases. Cancer Lett. 2008;262(1):77-86.

45. Leeper-Woodford SK, Detmer K. Acute hypoxia increases alveolar macrophage tumor necrosis factor activity and alters NF-kappaB expression. Am J Physiol. 1999;276(6 Pt 1):L909-916.

46. Negus RP, Turner L, Burke F, Balkwill FR. Hypoxia down-regulates MCP-1 expression: implications for macrophage distribution in tumors. J Leukoc Biol. 1998;63(6):758-65.

47. Royds JA, Dower SK, Qwarnstrom EE, Lewis CE. Response of tumour cells to hypoxia: role of p53 and NFkB. Molecular Pathology: MP. 1998;51 (2):55-61.

48. Benoit M, Desnues B, Mege JL. Macrophage polarization in bacterial infections. J Immunol. 2008;181(6):3733-9.

49. Bingle L, Brown NJ, Lewis CE. The role of tumour-associated macrophages in tumour progression: implications for new anticancer therapies. J Pathol. 2002:196(3):254-65.

50. Gordon S, Taylor PR. Monocyte and macrophage heterogeneity. Nat Rev Immunol. 2005;5(12):953-64.

51. Nathan CF. Secretory products of macrophages. J Clin Invest. 1987;79(2):319-26.

52. Mills CD, Lenz LL, Ley K. Macrophages at the fork in the road to health or disease. Front Immunol. 2015;6:59.

53. Murray PJ, Wynn TA. Obstacles and opportunities for understanding macrophage polarization. J Leukoc Biol. 2011;89(4):557-63.

54. Sica A, Larghi P, Mancino A, Rubino L, Porta C, Totaro MG, et al. Macrophage polarization in tumour progression. Semin Cancer Biol. 2008;18(5):349-55.

55. Mantovani A, Sozzani S, Locati M, Allavena P, Sica A. Macrophage polarization: tumor-associated macrophages as a paradigm for polarized M2 mononuclear phagocytes. Trends Immunol. 2002;23(11):549-55.

56. Solinas G, Germano G, Mantovani A, Allavena P. Tumor-associated macrophages (TAM) as major players of the cancer-related inflammation. J Leukoc Biol. 2009:86(5):1065-73.

57. Condeelis J, Pollard JW. Macrophages: obligate partners for tumor cell migration, invasion, and metastasis. Cell. 2006;124(2):263-6.

58. Kolls JK, Linden A. Interleukin-17 family members and inflammation. Immunity. 2004;21(4):467-76.

59. Verreck FA, de Boer T, Langenberg DM, Hoeve MA, Kramer M, Vaisberg E, et al. Human IL-23-producing type 1 macrophages promote but IL-10producing type 2 macrophages subvert immunity to (myco)bacteria. Proc Natl Acad Sci U S A. 2004:101(13):4560-5.

60. Mantovani A, Sica A, Allavena P, Garlanda C, Locati M. Tumor-associated macrophages and the related myeloid-derived suppressor cells as a paradigm of the diversity of macrophage activation. Hum Immunol. 2009;70(5):325-30.

61. Kigerl KA, Gensel JC, Ankeny DP, Alexander JK, Donnelly DJ, Popovich PG. Identification of two distinct macrophage subsets with divergent effects causing either neurotoxicity or regeneration in the injured mouse spinal cord. J Cogn Neurosci. 2009;29(43):13435-44.

62. Lamagna C, Aurrand-Lions M, Imhof BA. Dual role of macrophages in tumor growth and angiogenesis. J Leukoc Biol. 2006;80(4):705-13.

63. Wang J, Wakeham J, Harkness R, Xing Z. Macrophages are a significant source of type 1 cytokines during mycobacterial infection. J Clin Invest. 1999;103(7):1023-9.

64. Beck AH, Espinosa I, Edris B, Li R, Montgomery K, Zhu S, et al. The macrophage colony-stimulating factor 1 response signature in breast carcinoma. Clinical cancer research : an official journal of the American Association for Cancer Research. 2009;15(3):778-87.

65. Siveen KS, Kuttan G. Role of macrophages in tumour progression. Immunol Lett. 2009;123(2):97-102.

66. Sunderkotter C, Steinbrink K, Goebeler M, Bhardwaj R, Sorg C. Macrophages and angiogenesis. J Leukoc Biol. 1994;55(3):410-22.
67. Aksamit RR, Falk W, Leonard EJ. Chemotaxis by mouse macrophage cell lines. J Immunol. 1981;126(6):2194-9.

68. Ong SM, Tan YC, Beretta O, Jiang D, Yeap WH, Tai JJ, et al. Macrophages in human colorectal cancer are pro-inflammatory and prime T cells towards an anti-tumour type-1 inflammatory response. Eur J Immunol. 2012;42(1):89-100.

69. Alves AC, Etxebarria A, Soutar AK, Martin C, Bourbon M. Novel functional APOB mutations outside LDL-binding region causing familial hypercholesterolaemia. Hum Mol Genet. 2014:23(7):1817-28.

70. Cramer T, Johnson RS. A novel role for the hypoxia inducible transcription factor HIF-1alpha: critical regulation of inflammatory cell function. Cell Cycle. 2003;2(3):192-3.

71. Cramer T, Yamanishi Y, Clausen BE, Forster I, Pawlinski R, Mackman N, et al. HIF-1alpha is essential for myeloid cell-mediated inflammation. Cell. 2003;112(5):645-57.

72. Biswas SK, Gangi L, Paul S, Schioppa T, Saccani A, Sironi M, et al. A distinct and unique transcriptional program expressed by tumor-associated macrophages (defective NF-kappaB and enhanced IRF-3/STAT1 activation). Blood. 2006;107(5):2112-22.

73. Sakai Y, Honda M, Fujinaga H, Tatsumi I, Mizukoshi E, Nakamoto Y, et al. Common transcriptional signature of tumor-infiltrating mononuclear inflammatory cells and peripheral blood mononuclear cells in hepatocellular carcinoma patients. Cancer Res. 2008;68(24):10267-79.

74. Shimoyamada H, Yazawa T, Sato H, Okudela K, Ishii J, Sakaeda M, et al. Early growth response-1 induces and enhances vascular endothelial growth factor-A expression in lung cancer cells. Am J Pathol. 2010;177(1):70-83

75. Riabov V, Gudima A, Wang N, Mickley A, Orekhov A, Kzhyshkowska J. Role of tumor associated macrophages in tumor angiogenesis and lymphangiogenesis. Frontiers in Physiology. 2014:5:75.

76. Giraudo E, Inoue M, Hanahan D. An amino-bisphosphonate targets MMP-9-expressing macrophages and angiogenesis to impair cervical carcinogenesis. J Clin Invest. 2004;114(5):623-33.

77. Khan MA, Jiang X, Dhillon G, Beilke J, Holers VM, Atkinson C, et al. CD4+ T cells and complement independently mediate graft ischemia in the rejection of mouse orthotopic tracheal transplants. Circ Res. 2011;109(11):1290-301.

78. Stephan AH, Barres BA, Stevens B. The complement system: an unexpected role in synaptic pruning during development and disease. Annu Rev Neurosci. 2012;35:369-89.

79. Langer HF, Chung KJ, Orlova W, Choi EY, Kaul S, Kruhlak MJ, et al. Complement-mediated inhibition of neovascularization reveals a point of convergence between innate immunity and angiogenesis. Blood. 2010;116(22):4395-403.

80. Ricklin D, Lambris JD. Complement in immune and inflammatory disorders: pathophysiological mechanisms. J Immunol. 2013;190(8):3831-8.

81. Mastellos D, Lambris JD. Complement: more than a 'guard' against invading pathogens? Trends Immunol. 2002;23(10):485-91.

82. Niculescu F, Rus H, van Biesen T, Shin ML. Activation of Ras and mitogenactivated protein kinase pathway by terminal complement complexes is $G$ protein dependent. J Immunol. 1997;158(9):4405-12.

83. Rus H, Niculescu F, Badea T, Shin ML. Terminal complement complexes induce cell cycle entry in oligodendrocytes through mitogen activated protein kinase pathway. Immunopharmacology. 1997;38(1-2):177-87.

84. Vaupel P. The role of hypoxia-induced factors in tumor progression. Oncologist. 2004:9 Suppl 5:10-7.

85. Bluff JE, Brown NJ, Reed MW, Staton CA. Tissue factor, angiogenesis and tumour progression. Breast Cancer Res. 2008:10(2):204.

86. Lucas SD, Karlsson-Parra A, Nilsson B, Grimelius L, Akerstrom G, Rastad J, et al. Tumor-specific deposition of immunoglobulin $\mathrm{G}$ and complement in papillary thyroid carcinoma. Hum Pathol. 1996;27(12):1329-35.

87. Bu X, Zheng Z, Wang C, Yu Y. Significance of C4d deposition in the follicular lymphoma and MALT lymphoma and their relationship with follicular dendritic cells. Pathol Res Pract. 2007;203(3):163-7.

88. Schlesinger M, Broman I, Lugassy G. The complement system is defective in chronic lymphatic leukemia patients and in their healthy relatives. Leukemia. 1996;10(9):1509-13.

89. Kraut EH, Sagone Jr AL. Alternative pathway of complement in multiple myeloma. Am J Hematol. 1981;11(4):335-45.

90. Kalwinsky DK, Urmson JR, Stitzel AE, Spitzer RE. Activation of the alternative pathway of complement in childhood acute lymphoblastic leukemia. J Lab Clin Med. 1976;88(5):745-56. 
91. Ytting $H$, Jensenius JC, Christensen IJ, Thiel S, Nielsen HJ. Increased activity of the mannan-binding lectin complement activation pathway in patients with colorectal cancer. Scand J Gastroenterol. 2004;39(7):674-9.

92. Bamberg CE, Mackay CR, Lee H, Zahra D, Jackson J, Lim YS, et al. The C5a receptor (C5aR) C5L2 is a modulator of C5aR-mediated signal transduction. J Biol Chem. 2010;285(10):7633-44.

93. Li K, Anderson KJ, Peng Q, Noble A, Lu B, Kelly AP, et al. Cyclic AMP plays a critical role in C3a-receptor-mediated regulation of dendritic cells in antigen uptake and T-cell stimulation. Blood. 2008;112(13):5084-94.

94. Strainic MG, Liu J, Huang D, An F, Lalli PN, Muqim N, et al. Locally produced complement fragments C5a and C3a provide both costimulatory and survival signals to naive CD4+ T cells. Immunity. 2008;28(3):425-35.

95. Kobayashi S, Nagaura T, Kimura I, Kimura M. Interferon-gamma-activated macrophages enhance angiogenesis from endothelial cells of rat aorta. Immunopharmacology. 1994;27(1):23-30.

96. Nucera S, Biziato D, De Palma M. The interplay between macrophages and angiogenesis in development, tissue injury and regeneration. Int J Dev Biol. 2011;55(4-5):495-503.

97. Pollard JW. Macrophages define the invasive microenvironment in breast cancer. J Leukoc Biol. 2008;84(3):623-30.

98. Redente EF, Dwyer-Nield LD, Merrick DT, Raina K, Agarwal R, Pao W, et al. Tumor progression stage and anatomical site regulate tumor-associated macrophage and bone marrow-derived monocyte polarization. Am J Pathol. 2010;176(6):2972-85.

99. Schrader J, Herkel J. Chronic liver inflammation dominated by interferongamma can prevent hepatocarcinogenesis. Oncoimmunology. 2012;1(2):222-3.

100. Melis JP, Strumane K, Ruuls SR, Beurskens FJ, Schuurman J, Parren PW. Complement in therapy and disease: Regulating the complement system with antibody-based therapeutics. Mol Immunol, 2015.

101. Coussens LM, Pollard JW. Leukocytes in mammary development and cancer. Cold Spring Harbor perspectives in biology 3(3), 2011.

102. de Rezende LC, Silva IV, Rangel LB, Guimaraes MC. Regulatory T cell as a target for cancer therapy. Arch Immunol Ther Exp (Warsz). 2010;58(3):179-90.

103. Oxnard GR, Binder A, Janne PA. New targetable oncogenes in non-small-cell lung cancer. J Clin Oncol. 2013;31(8):1097-104.

104. Ribas A. Tumor immunotherapy directed at PD-1. N Engl J Med. 2012;366(26):2517-9.

105. Zipfel PF, Skerka C. Complement regulators and inhibitory proteins. Nat Rev Immunol. 2009;9(10):729-40.

106. Hollingsworth MA, Swanson BJ. Mucins in cancer: protection and control of the cell surface. Nature reviews. Cancer. 2004;4(1):45-60.

107. Woodruff TM, Nandakumar KS, Tedesco F. Inhibiting the C5-C5a receptor axis. Mol Immunol. 2011;48(14):1631-42.

108. Cole DS, Morgan BP. Beyond lysis: how complement influences cell fate. Clin Sci. 2003;104(5):455-66

109. Kraus S, Seger R, Fishelson Z. Involvement of the ERK mitogen-activated protein kinase in cell resistance to complement-mediated lysis. Clin Exp Immunol. 2001;123(3):366-74.

110. Niculescu F, Badea T, Rus H. Sublytic C5b-9 induces proliferation of human aortic smooth muscle cells: role of mitogen activated protein kinase and phosphatidylinositol 3-kinase. Atherosclerosis. 1999;142(1):47-56.

111. Tegla CA, Cudrici C, Patel S, Trippe 3rd R, Rus V, Niculescu F, et al. Membrane attack by complement: the assembly and biology of terminal complement complexes. Immunol Res. 2011;51(1):45-60.

112. Zipfel PF. Complement and immune defense: from innate immunity to human diseases. Immunol Lett. 2009;126(1-2):1-7.

\section{Submit your next manuscript to BioMed Central and take full advantage of:}

- Convenient online submission

- Thorough peer review

- No space constraints or color figure charges

- Immediate publication on acceptance

- Inclusion in PubMed, CAS, Scopus and Google Scholar

- Research which is freely available for redistribution

Submit your manuscript at www.biomedcentral.com/submit 